\title{
Microbiota and Women's Health
}

\author{
Sadi Turgut Bilgi \\ Faculty of Health Sciences, Canakkale Onsekiz Mart University, \\ Canakkale, Turkey \\ E-mail: stbilgi@comu.edu.tr
}

\begin{abstract}
All our genes together are called genomes. The Human Genome Project (HGP), an international collaborative research program, was conducted to fully map and understand the human genome. The sum of the genes of all microorganisms closely related to our genome is called microbiome. Following the completion of the Human Genome Project (HGP), the Human Microbiome Project (HMP) was conducted in which all microorganisms in different anatomical regions of our body were investigated. In this review, microbiome characteristics of oral cavity, skin, nasal cavity, digestive system and urogenital regions of donors in HMP studies were discussed. Special attention was paid to current microbiome research on women and child health. In the Integrative Human Microbiome Project (iHMP), which is considered as the continuation of HMP, pregnancy and preterm birth constitute one of the three main topics, which shows the importance given to women and child health. It was reported in the findings of HMP that there was no core microbiome in the urogenital microbiota, but the dysbiosis that occurred had a negative effect on the health of women and children. More and more evidence shows that human microbiome plays important role in human health and disease. In this context, it is provided that human microbiome research will be transformed into individual diagnostic, therapeutic and preventive applications in the field of health.
\end{abstract}

Keywords: Microbiota, Urogenital microbiota, Pregnancy, Neonatal

DOI: $10.7176 /$ JSTR/6-01-04

\section{Mikrobiyota ve Kadın Sağlığı}

Bütün genlerimiz birarada genom olarak adlandırılmaktadır. İnsan genomunun tam olarak haritalanması ve anlaşılması amacıyla uluslararası iş birliğine dayalı bir araştırma programı olan İnsan Genom Projesi (HGP) yürütülmüştür. Genomumuz ile yakın ilişkili tüm mikroorganizmaların genlerinin toplamı ise mikrobiyom olarak isimlendirilmektedir. İnsan Genom Projesinin (HGP) tamamlanmasının ardından vücudumuzun farklı anatomik bölgelerindeki mikroorganizmaların tümünün araştırıldığı İnsan Mikrobiyom Projesi (HMP) yürütülmüştür. Bu derlemede HMP çalışmalarındaki donörlerin ağız boşluğu, deri, nazal boşluk, sindirim sistemi ve ürogenital bölgelerinin mikrobiyom özelliklerine değinilmiştir. Özellikle kadın ve çocuk sağlığı üzerine yapılan güncel mikrobiyom araştırmalarına dikkat çekilmiştir. HMP'nin devamı olarak düşünülen Bütünleştirici İnsan Mikrobiyom Projesinde (iHMP) gebelik ve erken doğumun üç ana başlıktan birini oluşturması kadın ve çocuk sağlığına verilen önemi göstermektedir. Ürogenital mikrobiyotada çekirdek bir mikrobiyom bulunmadığı ancak meydana gelen dengesizliklerin kadın ve çocuk sağlığını olumsuz yönde etkilediği HMP'nin bulgularında rapor edilmiştir. Gittikçe daha fazla sayıda kanıt, insan mikrobiyomunun insan sağlığı ve hastalıklarında önemli rol oynadığını göstermektedir. Bu bağlamda insan mikrobiyom araştırmalarının sağlık alanında kişiye özgü tanısal, tedavi edici ve önleyici uygulamalara dönüşmesi öngörülmektedir.

Anahtar Kelimeler: Mikrobiyota, Ürogenital mikrobiyota, Gebelik, Yenidoğan

\section{Giriş}

İnsanlar ve tüm genleriyle yakın ilişki içinde yaşayan tüm bakterilerin toplamı mikrobiyom olarak adlandırılmaktadır (Aagaard ve ark., 2014). İnsan mikrobiyomu vücudumuzun içinde ve yüzeyinde bulunan bakteri, archaea, virüs ve ökaryotik mikroorganizmalardan oluşur. Bu mikroorganizmalar hem sağlıkta hem de hastalıkta fizyolojimizi etkileyen muazzam bir potansiyele sahiptir. Mikrobiyom 
çalışmalarının tarihçesine bakıldığında mikrobiyolojinin babası ve mikroskobun mucidi olarak bilinen Antonie Van Leeuwenhoek kendi dişlerinden kazınmış biyofilmi kullanarak insan bakteri topluluğunu ilk kez gözlemlemesi ile insan mikrobiyom araştırmalarının temelini atmıştır (Martin, 2012). Ardından 1953 'te James Watson ve Francis Crick tarafından DNA'nın çift zincirli sarmal yapısının keşfi, 1977'de Frederic Sanger tarafından DNA dizileme tekniğinin geliştirmesi, moleküler ve genetik alanındaki gelişmeler ile birlikte insan hücrelerinin genetiğinin incelenmeye başlanması gibi dönüm noktalarına sahiptir (Roberts, 2001). Bütün genlerimiz birarada "genom" olarak adlandırılır. İnsan Genom Projesi (HGP, 1990-2003), insanın tüm genlerinin tam olarak haritalanması ve anlaşılmasını amaçlayan uluslararası iş birliğine dayalı bir araştırma programı olmuştur. HGP sonuçlarına göre insan genomunun yaklaşık 3 milyar DNA baz çiftinden ve 20.000-25.000 protein-kodlayıcı gen içeriğinden oluştuğu ifade edilmiştir (IHGSC, 2004). Bu proje kapsamında birçok farklı veri kaynağı iki bireyin \% 99,9'dan fazla oranda genetik benzerliğe sahip olduğu ve bireyler arasındaki farklılıkların \% 0,1'lik orandaki genetik farklılıktan meydana geldiğini göstermiştir (Venter ve ark., 2001). Bununla birlikte HGP'de uygulanan modern genomik teknikler mikrobiyal organizma topluluklarının doğal ortamlarında doğrudan çalışılmasına olanak tanımış (Chen ve Pachter, 2005) ve insan mikrobiyomunun tüm genom analiz tekniklerinde önemli ilerlemeler sağlamıştır (Turnbaugh, 2007; Gritz ve Bhandari, 2015). Bu sayede dünya mikrobiyomu (Gilbert ve ark., 2014), hastane mikrobiyomu (Smith ve ark., 2013), ev mikrobiyomu (Lax ve ark., 2014), köpek mikrobiyomu (Gilbert, 2015) gibi birçok alanda mikrobiyom projeleri yürütülmüştür. Aralarında en dikkat çekici 2008-2013 yılları arasında Ulusal Sağlık Enstitüleri (NIH) desteği ile gerçekleştirilmiş İnsan Mikrobiyom Projesi (HMP) olmuştur (Qin ve ark., 2010). Bu proje sayesinde her bir vücut bölgesinin diş çevreyle bağlantılı yüzey ve boşluklarda konak ile mutual bir yaşam sergileyen ekolojik mikrobiyal topluluklar incelenmiştir (Ravel ve ark., 2011; Krishna ve ark., 2017).

İnsanlar ve mikrobiyomlarının metabolik ve antijenik çeşitliliğe sahip farklı vücut bölgelerinin nişlerinden oluşan fizyolojik bir topluluk olarak birlikte geliştiği düşünülmektedir (Aagaard ve ark., 2014). Bu mikroorganizmaların binlerce yıl boyunca insanlarla birlikte gelişerek hayatta kalmamız için besin maddelerinin emilimi ve doğal bağışıklığın oluşturulması gibi kritik öneme sahip oldukları ifade edilmektedir. Son dönemlerde yapılan çalışmalar bu birlikte yaşam mekanizmalarının anlaşılmasına yöneliktir (Martin, 2012). Derlememizde farklı anatomik bölgelerdeki insan mikrobiyomu ile kadın ve çocuk sağlığı üzerine etkilerini araştıran güncel çalışmalar analiz edilmeye çalışılmıştır.

\section{2. İnsan mikrobiyomu}

Dünya genelinde $10^{30}$ kadar mikrobiyal hücre bulunduğu düşünülmekle birlikte, sadece insan vücudunda, bakteriler, virüsler, mantarlar ve birçok mikro-ökaryottan oluşan, 100 trilyon $\left(10^{14}\right)$ kadar mikroorganizma olduğu tahmin edilmektedir (Di Bella ve ark., 2013). İnsan vücudu, kendi hücrelerinden $\left(10^{13}\right)$ en az on kat daha yüksek sayıda karmaşık bir mikroorganizma topluluğuna $\left(10^{14}\right)$ ve onların genlerine (mikrobiyom) ev sahipliği yapmaktadır (Ravel ve ark., 2011; Krishna ve ark., 2017). İnsan mikrobiyomunu oluşturan organizmaların \% 10'undan daha azının kültüre edilemediği kabul edilmektedir (Dethlefsen ve ark., 2007; Martin, 2012). Temelde, mikrobiyomumuzdaki genlerin tamamına yakını $(\% 99,1)$ bakteri, geri kalanı çoğunlukla arkeal ve sadece \% 0,1'lik kısmı ökaryotik ve viral kökenlidir (Qin ve ark., 2010).

İnsan mikrobiyom projesi (HMP) kapsamında sağlıklı yetişkin 242 donörün üç tekrarlı olarak 18 (kadın) ve 15 (erkek) ayrı vücut bölgesinden elde edilen mikrobiyal örnekler analiz edilmiştir. Kadın donörler için ağız boşluğu, deri, nazal boşluk, sindirim sistemi ve vajen olmak üzere beş ana vücut bölgesinden örnekler alınmıştır. Ana örnek grupları incelendiğinde ağız boşluğundan tükürük, yanak, diş etleri, damak, bademcikler, boğaz ve dil yumuşak dokuları ve diş etinin alt ve üst biyofilmi olmak üzere dokuz örnek toplanmıştır. Deriden her iki kulak arkası ve iç dirsekten toplam 4 ve nazal boşluk için burun deliğinden 1 örnek alınmıştır. Sindirim sistemini temsilen 1 dışkı örneği ve vajenin açıklık, orta ve posteriör forniksi olmak üzere 3 farklı bölgesinden örnekleme yapılmıştır. Toplamda 4,788 örnek, 3.5 terabazlık metagenomik dizi ve $16 \mathrm{~S}$ ribozomal RNA genlerinden 5,177 mikrobiyal taksonomik profil üretilmiştir. Bununla birlikte İnsan vücudundan izole edilen yaklaşık 800 referans strain dizilenmiştir. İnsan mikrobiyom projesi verilerinin, mevcut ve gelecekteki çalışmalar için bir çerçeve sağlayacağı, insan mikrobiyomunun bolluğunu ve çeşitliliğini tanımlayan en büyük kaynağı temsil edeceği ifade edilmiştir (Methé ve ark., 2012).

$\mathrm{Bu}$ kaynak verileri kullanılarak HMP programının devamı ya da HMP'nin ikinci aşaması olarak nitelendirilen Bütünleştirici İnsan Mikrobiyom Projesi (iHMP) 2014 yılında oluşturulmuş ve yine NIH 
tarafından desteklenmektedir. iHMP programının amacının hem mikrobiyomdan hem de çoklu "omik" teknolojilerini kullanan mikrobiyomla ilişkili üç farklı kohort çalışmasından biyolojik özelliklere ait veri kümelerinin oluşturulması olduğu ifade edilmiştir. Bu bağlamda iHMP üç farklı kohort olarak gebelik ve erken doğum, inflamatuar barsak hastalığının Başlangıcı (IBD), tip 2 diyabetin Başlangıcı projeleri yürütülmektedir. HMP ve iHMP projelerinden gelen veri kümeleri ve kaynaklar ortak bir veri koordinasyon merkezinde toplanacağı bildirilmiştir (iHMP, 2014).

HMP'de elde edilen devasa veriler kullanılarak insan mikrobiyom habitatlarındaki popülasyon değişimleri analiz edilmiştir. Bu sayede donör içi varyasyonların hem organizmal hemde metabolik fonksiyonda, donörler arasındaki varyasyondan düşük olduğu tespit edilmiştir. Bu nedenle, her bir donör mikrobiyomunun benzersizliği, nüfusa göre zaman içinde istikrarlı görünmesi, sağlıkla ilişkili insan mikrobiyomunun bir başka özelliği olabileceği vurgulanmıştır (Huttenhower ve ark., 2012).

İnsan mikrobiyom projesi sonuçlarından biri olarak her ne kadar birkaç mikroorganizma grubu geniş prevalans göstermiş olsa da tüm vücut habitatları ve bireyler arasında evrensel bir mikroorganizma sınıfının bulunmadığı tespit edilmiştir (Huttenhower ve ark., 2012). HMP kapsamında özellikle kadın ve çocuk sağlığını dikkate alan temel vücut bölgelerine ait mikrobiyomlar üzerine yapılan çalışmalar aşağıda özetlenmeye çalışılmıştır.

\subsection{Oral Mikrobiyom}

Sağlıklı bir insanın ağız boşluğundaki kültüre edilmiş ve edilmemiş bakteri çeşitliliği üzerine yapılan bir araştırmada 9 bölge incelenmiştir. Bu bölgelerden (dil dorsumu, dilin lateral yüzleri, bukkal epitel, sert damak, yumuşak damak, diş yüzeylerinin supragingival plağı, subgingival plak, maksiller anterior antrikül ve bademcikler) elde edilen örneklerlerden 141 baskın tür tespit edilmiştir. Bu çalışmada sağlıklı bir insanın ağız boşluğunun oldukça çeşitlilik gösterdiği, bölgeye ve özneye özgü belirgin bir baskın bakteri florasının var olduğu ve Gemella, Granulicatella, Streptococcus ve Veillonella cinslerine ait türlerin tüm bölgelerde ortak oldukları belirtilmiştir (Aas ve ark., 2005). Benzer bir çalışmada taksonomik olarak Porphyromonadaceae, Veillonellaceae ve Lachnospiraceae ailelerinin tüm ağı boşluğu bölgelerinde ortak, ancak cinslerinin dağılımı önemli ölçüde değiştiği ifade edilmiştir (Segata ve ark., 2012). Aynı çalışmada boğaz ve bademciklerde koloni oluşturan önemli insan patojeni olarak bilinen Streptococcus pneumoniae, Streptococcus pyogenes, Neisseria meningitidis ve Haemophilus influenza türlerinin üst sindirim sistemi bölgelerinin mikrobiyomunda iyi bir şekilde temsil edildiği vurgulanmıştır (Segata ve ark., 2012). Özellikle, daha az baskın sınıflar hem bireyler hem de vücut habitatları arasında oldukça özelleşmiştir (Huttenhower ve ark., 2012). Aynı çalışmada ağız boşluğunda çoğu habitatın Streptococcus cinsinin egemenliğinde olduğu ancak yanak mukozasında Haemophilus, supragingival plakta Actinomyces ve subgingival (düşük oksijen içeriği) plakta Prevotella cinsleri bol miktarda bulunduğu ifade edilmiştir (Segata ve ark., 2012). Tükürük örneklerinin mikrobiyomlarının incelendiği bir çalışmada türler düzeyindeki sınıflandırma verileri karşılaştırıldığında tükürük mikrobiyomu en yüksek alfa çeşitliliğine (komünite içi çeşitlilik) sahip olmasına rağmen beta çeşitlilikte (komüniteler arası çeşitlilik) en düşük örnekler arasında olduğu bildirilmiştir. Bu nedenle her bir bireyin tükrüğünün ekolojik yönden zengin olmasına karşın popülasyon üyelerinin benzer mikroorganizmaları paylaştığı ifade edilmiştir (Huttenhower ve ark., 2012).

\subsection{Cilt mikrobiyomu}

Deri, bol miktarda kıvrım, yayılma ve çok çeşitli mikroorganizmaları destekleyen özel nişlerden ve farklı habitatlardan oluşan 1,8 $\mathrm{m}^{2}$ 'lik bir ekosistemdir. Sağlıklı yetişkinler üzerine yapılan araştırmalarda mikrobiyal toplulukların kompozisyonunun cilt bölgesinin fizyolojisine bağlı olduğu bulunmuştur (Grice ve Segre, 2011). Bununla birlikte meslek, giysi seçimi ve antibiyotik kullanımı gibi bireye özgü çevresel faktörlerin de cilt mikrobiyotası kolonizasyonunu etkilediği bildirilmiştir (Byrd ve ark., 2018).

Yağlı bölgelerde lipofilik Propionibacterium türleri hakimken dirseklerin ve ayakların kıvrımları dahil nemli bölgelerde Staphylococcus ve Corynebacterium türleri ile kuru bölgelerde $\beta$-Proteobakteriler ve Flavobacteriales gibi karışık bakteri popülasyonları gözlenmiştir (Grice ve ark., 2009; Byrd ve ark., 2018). Yenidoğan çalışmaları incelendiğinde cildin ilk kolonizasyonunun doğum moduna bağlı olduğu, normal yolla yenidoğanlarda vajinayı kolonize eden bakterilerin (Lactobacillus, Prevotella ve Sneathia spp.), sezaryen yenidoğanlarda cilt ile ilişkili olan bakterilerin (Staphylococcus, Corynebacterium ve Propionibacterium spp.) izole edildiği bildirilmiştir (Dominguez-Bello ve ark., 2010). Araştırmacılar yenidoğanlarda bu ilk cilt kolonizasyon modlarının uzun vadeli etkilerinin hala bilinmemesi nedeniyle ileri metagenomik analizlerin yapılması görüşündedirler (Byrd ve ark., 2018).

37 | $P$ a g e 
Diğer yandan deride yapılan bir araştırmada, hastane enfeksiyonu olarak bilinen metisilin dirençli Staphylococcus aureus (MRSA) bakterisinin kaynağı olan Staphylococcus aureus türünün taşınma oranının burunda $\% 29$ ve deride $\% 4$ olduğu bildirilmiştir (Kuehnert ve ark., 2006). Benzer çalışmalarda kommensal olarak kabul edilen Staphylococcus epidermidis gibi yakın filogenetik akrabaların, S. aureus aksine, cilt üzerinde evrensel olması ve burun örneklerinin \%93'ünde bulunduğu, Gram negatif cilt patojenini temsilen Pseudomonas aeruginosa türünün her iki vücut bölgesinde de bulunmadığ ifade edilmiştir (Kuehnert ve ark., 2006; Huttenhower ve ark., 2012). Bu veriler dikkate alındığında cilt mikrobiyomunda en yüksek beta çeşitliliğin dirsek içinde olduğu ancak aynı bölgede alfa çeşitliliğin orta seviyede olduğu ifade edilmiştir (Huttenhower ve ark., 2012).

Cilt mikrobiyomu üzerine yapılan farklı bir çalışmada parmak uçlarında bulunan mikrobiyal parmak izi olarak adlandırılan bakterilerin bir klavyede izlenebileceği, böylece bakteri kalıntısına göre hangi kişinin hangi tuşları kullandığının belirlenebileceği, dolayısıyla cilt mikrobiyomunun adli bir potansiyele sahip olduğu ifade edilmiştir (Fierer ve ark., 2010). Benzer çalışmalarda cep telefonlarının sahibine ait kişisel mikrobiyal imzalarını taşıdığı bildirilmiştir (Meadow ve ark., 2014; Lax ve ark., 2015). Bahsedilen cilt mikrobiyom çalışmaları gelecekteki adli araştırmalar için pilot çalışma olarak değerlendirilmektedir (Hampton-Marcell ve ark., 2017).

\subsection{Nazal Mikrobiyom}

İnsan burun mukozası çok sayıda mikroorganizmaya ev sahipliği yapmaktadır. Kommensal mikroorganizmalar ve metabolitleri, simbiyotik bir sistemde habitatlarının stabilitesini korurken, bu kommensal yerleşik mikroorganizmaların ve patojenlerin bileşimindeki bozukluklar, iltihaplanmanın başlangıcında ve potansiyel olarak ilerlemesinde önemli rol oynar (Mahdavinia ve ark., 2016). Nazal mikrobiyota bakteriyel filum düzeyinde nispeten düşük bir çeşitliliğe sahiptir (Biswas ve ark., 2015). Sağlıklı yetişkinlerin nazal boşluk mikrobiyotasının incelendiği bir çalışmada ağırlıklı olarak Corynebacterium $(\% 29,5)$, Staphylococcus $(\% 14,4)$, Propionibacterium $(\% 13,1)$, Moraxella $(\% 6,8)$, Gordonia $(\% 3,4)$ ve Streptococcus $(\% 3,4)$ cinsi bakterilerin bulunduğu bildirilmiştir (Bassis ve ark., 2014). Nazal mikrobiyomdaki türler üzerine yapılan bir çalıșmada bu bölgelerde en zengin mikroorganizma topluluklarının Staphylococcus aureus, Staphylococcus epidermidis ve Propionibacterium acnes olduğu belirtilmiştir (Ramakrishnan ve ark., 2018). 236 sağlıklı yetişkinden alınan nazal örneklerin incelendiği farklı bir araştırmada ciltte Staphylococcus sp. taşınımının en fazla nazal bölgede olduğu bildirilmiş̧ir (Zhou ve ark., 2014). Farklı nazal bölgelerin mikrobiyotasının ayrı ayrı incelendiği bir çalışmada sağlıklı bireyler ve kronik rinosinüzit hastalar karşılaştırıldığında bakteri çeşitliliği, kompozisyonu veya bolluğu açısından anlamlı bir fark olmadığı hatta burun boșluğunun farklı bölgelerinin benzer mikrobiyotaya sahip olduğu tespit edilmiştir (Biswas ve ark., 2015). Farklı araştımacılar tarafindan sağlıklı bireylerde yetişkin burun mikrobiyomunun, hastalık durumlarından daha iyi karakterize edildiği dolayısıyla nazal mikrobiyom gelişiminin daha fazla araştııılması gerektiği belirtilmiştir (Rawls ve Ellis, 2019).

\subsection{Gastrointestinal Mikrobiyom}

Vücudumuzdaki mikroorganizmaların toplu olarak 100 trilyon $\left(10^{14}\right)$ hücreden oluştuğu ve bu mikroorganizmaların yaklaşık $10^{11}$ hücresinin barsakta bulunduğu tahmin edilmektedir (Sender ve ark., 2016). Barsak mikrobiyomunun insan fizyolojisi ve beslenmesi üzerinde derin bir etkiye sahip olduğu ve insan yaşamı için çok önemli olduğu bilinmektedir (Qin ve ark., 2010). Gastrointestinal sistemde (GIS) toplam bakteri popülasyonunun mide ve ince barsaktaki düşük $\mathrm{pH}$ ve içeriğin hızlı akıșı nedeniyle ihmal edilebilir olduğundan önemli bir kısmı kolon tarafindan sağlanmaktadır (Sender ve ark., 2016). Sağlıklı insan mikrobiyomu üzerine yapılan bir araştırmada en çok çalışılan vücut bölgesinin intestinal mikrobiyota olduğu ifade edilmiştir (Lloyd-Price ve ark., 2016).

Yapılan dizileme çalışmaları sağlıklı barsak mikrobiyomlarında sürekli olarak Bacteroidetes ve Firmicutes bakteri şubelerinin baskın olarak bulunduğunu göstermiştir (Qin ve ark., 2010; Huttenhower ve ark., 2012). GíS mikrobiyotasının en çeșitli ve bol grubu Firmicutes şubesi olup, sağlıklı yetişkinlerin yaklaşık \%80'ini oluşturur. Firmicutes şubesi Bacilli, Clostridia, Erysipelotrichi ve Negativicutes olmak üzere dört sınıfa dağılmıştır. GİS'de yoğun olarak bulunan daha önce Bacteroides cinsi içinde sinıflandırılan türler Alistipes, Prevotella, Paraprevotella, Parabacteroides ve Odoribacter olmak üzere beş cins içerisinde tekrar sınıflandırılmıştır (Rajilić-Stojanović ve de Vos, 2014).

Her ne kadar bazı Bacteroides spp. türleri hala firsatçı patojenler olarak kabul edilse de son yıllarda yapılan araştırmalar, birçok Bacteroidetes türünün yüksek oranda yaşadıkları $\left(10^{11}\right.$ hücre/g intestinal 
materyal) GİS'e yüksek uyumlu olduğunu ispatlamıştır. Anne sütünün sindirilmeyen oligosakaritlerinin hem Bacteroides hem de Bifidobacterium spp. türlerinin büyümesini desteklediğinden, GíS'in Bacteroidetes ile kolonizasyonu bebeklerde teşvik edilmektedir (Marcobal ve ark., 2011; RajilicStojanovic ve de Vos, 2014). Baskın türlere ek olarak Proteobacteria şubesinde sinfflandırılan Escherichia coli türlerinin en iyi laboratuvar işçileri olarak bilinmesinin yanında çeşitli GíS ve ekstraintestinal enfeksiyonların etiyolojik ajanları olarak da bilinmektedirler. Bu bakteri türleri sağlıklı insan Gís'nde fekal maddede $10^{9} \mathrm{kob} / \mathrm{g}$ 'a ulaşacak kadar yaygındır. E. coli türünün patojen kolonizasyonunun önlenmesinde kritik bir rol oynadığı düşünülmekle birlikte, GíS mikrobiyomunun patojenik olmayan izolatların genomik çeşitliliği ve ekolojisi hakkında nispeten az şey anlaşıılmaktadır (Richter ve ark., 2018).

GİS mikrobiyomunun oluşumu hakkında önceleri yenidoğanların uterodayken tamamen mikroorganizmalardan yoksun olduğuna ve uterus çıkışında mikrobiyom gelişiminin başladığına inanılıyordu. Ancak son zamanlarda kobay fareler ile ile yapılan deneysel bir çalışmada, hamile farelerin genetik olarak etiketlenmiş bakterilerle oral yoldan tedavi edilmesinin, etiketlenmiş bakterilerin yavruların meconiumuna transfer edilmesine yol açtı̆̆ tespit edilmiştir (Jiménez ve ark., 2008). Hamilelik sırasında probiyotik tüketiminin yenidoğan mekonyumundaki etkileri üzerine yapılan bir çalışmada probiyotik tüketiminin Toll benzeri reseptör genlerini değiştirdiği gösterilmiştir (Rautava ve ark., 2012). Barsakta ilk kolonizasyonun, yenidoğanın karşılaştı̆̆ en derin immünolojik maruziyetlerden biri olduğu ve iç ve dış faktörlerden etkilendiği bilinmektedir. Bununla birlikte yapılan çalışmalarda insan mikrobiyotasının ilk kompozisyonunun uzun süre kalıcı metabolik etkiler sergileyecebileceği ve insan barsak bakterilerinin ilk kompozisyonunun doğum sonrası bağışıklık sistemi gelișimini etkileyebileceği ifade edilmiştir (Biasucci ve ark., 2010; Bäckhed ve ark., 2015). Yapılan çalışmalar barsak kolonizasyonunun doğumdan önce başladığına işaret etmektedir. Mikrobiyomun gelişimini etkileyebilecek tipik faktörler arasında ise doğum şekli, emzirme, çevresel maruziyetler, antibiyotikler ve duman soluma yer almaktadır (Man ve ark., 2017; Rawls ve Ellis, 2019).

Yaşamın ilk yılında insan barsak mikrobiyomu üzerine yapılan bir çalışmanın sonuçları, yenidoğan barsağının erken kolonizörlerinin çoğunun anneden kaynaklandığını ve doğum tarzının erken yaşamdaki bebeklerin barsak mikrobiyotasını belirleyen önemli bir faktör olduğunu göstermiştir (Bäckhed ve ark., 2015). Aynı çalışmada 12 ay emzirilen bebeklerin barsak mikrobiyomları, daha önce anne sütünde bulunan bakteriler olan Bifidobacterium, Lactobacillus, Collinsella, Megasphaera ve Veillonella türleri tarafindan baskın haldeyken (Jost ve ark., 2014) emzirmenin kesilmesi ile mikrobiyal ekolojiyi Bacteroides, Bilophila, Roseburia, Clostridium ve Anaerostipes türleri ile zenginleştirilmiş yetişkin benzeri bir oluşuma yönlendirdiği ifade edilmiştir. 12 aylık bebeklerin mikrobiyota yaşının emzirilmeyen bebeklerden daha genç göründüğü tespit edilmiş ve emzirmenin, yaşamın ilk y1lında barsak mikrobiyal topluluklarının şekillenmesinde ve artmasındaki rolü vurgulanmıştır (Bäckhed ve ark., 2015).

Polimeraz zincir reaksiyonu (PCR) denatüre edici gradyan jel elektroforezi (DGGE) ve PCR sıcaklık gradyan jel elektroforezi (TGGE) yöntemlerinin kullanılarak sezaryen (CS) ve normal doğan 46 örneğin GISS mikrobiyotasının incelendiği bir çalışmada yaşamın ilk 3 günü boyunca yenidoğanın barsak bakterilerinin çoğunlukla doğum şekli tarafindan etkilendiğini ve bunda beslenmenin çok az etkisinin olduğu bildirilmiştir (Biasucci ve ark., 2010). Aynı çalışmada CS doğan bebeklerin normal doğan bebeklere kıyasla daha az sayıda Bifidobacteria ve Bacteroides türlerine sahip olduğu bilindiğinden, doğum şeklinin erken bebeklik dönemi barsak mikrobiyomunun bileşimi üzerinde önemli bir role sahip olduğu ve barsak mikrobiyota kompozisyonunun postnatal adaptasyonun bir ölçüsü olarak görülmesi gerektiği ifade edilmiştir (Biasucci ve ark., 2010). Buna ek olarak bebeklik döneminde düşük mikrobiyal uyarılmanın bağışıklık sisteminin doğum sonrası olgunlaşmasının daha yavaş meydana gelmesinden dolayı yardımcı T hücreleri (Th) tarafindan oluşturulan Th1 ve Th2 benzeri bağışılılı arasında optimal bir dengenin geliştirilmesinin önem taşıdı̆̆ ifade edilmiştir (Biasucci ve ark., 2010).

Farklı çocukların ve yetişkinlerin lateral karşılaştırılmasının rapor edildiği bir araştırmada büyüyen bebeğin mikrobiyota gelişiminin zaman içinde daha karmaşık ve daha az farklılığa sahip olduğu dolayısıyla barsak mikrobiyotasındaki alfa $(\alpha)$-çeșitliliğin arttığı ve beta $(\beta)$-çeșitliliğin azaldığı gösterilmiştir (Bäckhed ve ark., 2015). Araştırmacılar tarafindan 16S rRNA'nın araştırılmasına dayanarak bebek mikrobiyomunun 3 yaşına kadar aşamalı olarak yetişkin benzeri bir yapıya olgunlaştığı sonucuna varılmıştır (Yatsunenko ve ark., 2012; Bäckhed ve ark., 2015). 


\section{5 Ürogenital Mikrobiyom}

Vajendeki bakterilerin vajinal homeostaziyi koruduğu ve bir dengesizlik veya disbiyoz durumunun zayıf üreme ve jinekolojik sağlık sonuçları ile ilişkili olabileceği uzun zamandır bilinmektedir (Muhleisen ve Herbst-Kralovetz, 2016). Bununla birlikte Işık mikroskobu ve kültür tekniklerinin gelişmesiyle yapılan birçok çalışma sağlıklı vajinal mikrobiyomlara Lactobacillus türlerinin hakim olduğunu göstermiştir. Yeni nesil dizileme teknolojisi, bilim insanlarının vajinal boşlukta yaşayan türlerin karmaşıklı̆ı̆ını ve çeşitliliğini daha fazla kategorize etmesini ve anlamasını sağlamıştır (Mühleisen ve Herbst-Kralovetz, 2016).

Bundan 20 sene öncesine kadar vajinadaki en yaygın Lactobacillus türünün L. crispatus olduğu düşünülmekteydi (Antonio ve ark., 1999). Ancak, yetişkin sağlıklı kadınlarda vajinal mikrobiyal toplulukların kültür-bağımsız yöntemler kullanarak karakterizasyonu üzerine yapılan çalışmalarda en yaygın vajinal bakteri türünün yetiştirilmesi zor ve geleneksel kültür ortamında yetişmeyen Lactobacillus iners olduğu tanımlanmıştır (Falsen ve ark., 1999; Zhou ve ark., 2004; Ma ve ark., 2012). HMP sonuçlarına göre vajinanın en düşük alfa çeşitliliğine, cins düzeyinde oldukça düşük beta çeşitliliğine sahip olduğu ancak farklı Lactobacillus alt türlerinin varlığı nedeniyle tür düzeyinde bu çeşitliliğin çok yüksek olduğu bildirilmiştir (Huttenhower ve ark., 2012). Lagier ve ark. (2018) şaşırtıcı bir şekilde vajinanın solunum yolu, ağız boşluğu ve barsak mikrobiyotasının dışındaki en çeşitli bakteriyosin rezervuarlarını içerdiğini ifade etmişlerdir.

Üreme çağındaki kadınların vajinal mikrobiyomları üzerine yapılan bir çalışmada dört etnik kökeni (siyah, beyaz, asyalı ve hispanik) eşit şekilde temsil eden 396 Kuzey Amerikalı kadın kohortunda vajinal mikrobiyal topluluklar karakterize edilmiștir. Bu çalışmanın sonuçları insan vajinası için tek çekirdekli mikrobiyom olmadığını göstermiştir. Aynı çalışmada örnekler beş gruba ayrılmış ve dört grupta Lactobacillus iners, L. crispatus, L. gasseri veya L. jensenii türlerinin baskın olarak bulunduğu beşinci grupta ise laktik asit bakterilerinin düşük oranda ve anaerobik organizmaların yüksek oranda olduğu bildirilmiştir. Ancak önemli bir ekolojik fonksiyon olan laktik asit üretiminin tüm topluluklarda korunduğu ifade edilmiştir (Ravel ve ark., 2011). Kültürden bağımsız teknikler kullanılarak yapılan kapsamlı vajinal mikrobiyal topluluk çalışmalarında Lactobacillus türlerinin kadınların çoğunda baskın vajinal bakteri türleri olduğu belirtilmiştir. Ancak aynı çalışmalarda sağlıklı kadınların \%20-30’unun asemptomatik olarak tanımlanan biraz daha yüksek $\mathrm{pH}(5.3-5.5)$ ile ilişkili çeşitli fakültatif veya zorunlu anaerobik bakteri dizisini içeren ve kayda değer miktarda Lactobacillus içermeyen vajinal toplulukları barındırdığı ifade edilmiştir (Zhou ve ark., 2004; Ravel ve ark., 2011; Ma ve ark., 2012). Yapılan çalışmalarda asemptomatik mikrobiyotanın Atopobium, Corynebacterium, Anaerococcus, Peptoniphilus, Prevotella, Gardnerella, Sneathia, Eggerthella, Mobiluncus ve Finegoldia cinslerini içerdiği bildirilmiştir (Zhou ve ark., 2004; Ravel ve ark., 2011). Ayrıca asemptomatik mikrobiyota üyelerinin çoğunun homolaktik veya heterolaktik asit fermantasyonu yapabilmesi sayesinde vajinal ekosistemleri koruyabildiği varsayılmaktadır (Zhou ve ark., 2004; Ravel ve ark., 2011). Bu nedenlerle asemptomatik mikrobiyata bileșimi bakteriyel vajinoz ile ilişkili olanlara yakından benzese de "normal" ve "sağlıklı" olarak kabul edilebilmektedir (Ma ve ark., 2012).

Bir kadının hayatındaki farklı evrelerde vajinal mikrobiyomun karakterizasyonu oldukça karmaşıktır (Martin, 2012). Yaş, adet ve östrojen seviyelerinin tümü bu mukozal bölgedeki mikrobiyatayı etkileyebilir (Hickey ve ark., 2012). En dramatik değişiklik, ergenlik döneminde östrojen ve glikojen seviyeleri arttı̆ğında görülmektedir. Bu artış, Lactobacillus türleri gibi laktik asit üreten bakteri üremesini teşvik eder ve bu durum genellikle bir kadının doğurgan olduğu yıllar boyunca korunur ve ardından menopozda düşüş gösterir (Mirmonsef ve ark., 2014). Patojenlerin kolonizasyonuna karşı korunmada antimikrobiyal bir rol oynayan asidik mikroçevre Lactobacillus türleri tarafindan üretilir (Muhleisen ve Herbst-Kralovetz, 2016).

İnsan mikrobiyomundaki biyosentetik gen kümelerinin (BGC- tiyopeptitlerin) sistematik analizinin yapıldığı farklı bir çalışmada klinik denemelerde bir antibiyotik sınıfı olan BGC'nin, insan mikrobiyotasının genomları ve metagenomları içinde yaygın bir şekilde dağıldığı keşfedilmiştir. Bu çalışmada yeni bir tiyopeptid antibiyotik olan laktosilinin vajinal mikrobiyotanın önemli bir üyesi Lactobacillus gasseri türünden elde edilerek saflaş̧ırıldığ bildirilmiştir. Ayrıca laktosilinin bir dizi Gram-pozitif vajinal patojene karşı güçlü antibakteriyel aktiviteye sahip olduğu da ortaya koyulmuştur (Donia ve ark., 2014). 


\subsubsection{Gebelikte Ürogenital Mikrobiyom}

Endometrium ve vajinal mikrobiyom anne ve yenidoğan sağlığında önemli bir rol oynamaktadır. Endometrium, kontamine olmayan numuneler elde etmedeki zorluklardan ve bakteriyal popülasyonun azlı̆̆ından dolayı metagenomik analiz için zorlu bir alan olarak kabul edilir. Gebelikte ürogenital mikrobiyotadaki dengesizlikler gebelik kaybı ve erken doğum gibi olumsuz üreme sonuçlarının etkeni olabilir ancak aralarındaki ilişkiler henüz kesin olarak tespit edilememiştir. Bu nedenle sağlıklı hamilelikte temel mikrobiyomun kapsamlı bir şekilde anlaşılması önem taşımaktadır (Freitas ve ark., 2017; Leoni ve ark., 2019).

İnsan vücudunun dış (dışkı, deri) veya iç (ağız, barsak, mide, ürogenital sistem, akciğerler) bölgelerininden alınan çoklu örneklerin karakterize edilmesinden sonra bazı vücut kısımlarının hala doğal olarak steril olduğu ifade edilmiştir. Yapılan araştırmalar yakın zamana kadar steril olduğu bilinen plesantanın aslında steril olmadığını göstermiştir (Aagaard ve ark., 2014; Wassenaar ve Panigrahi, 2014). İnsanlar ve mikrobiyomları üzerine yapılan 320 örnekli bir çalışmada $16 \mathrm{~S}$ rRNA tabanlı moleküler teknikler ve metagenomik veriler kullanılarak plasental mikrobiyom incelenmiștir. Bu çalışmada Firmicutes, Tenericutes, Proteobacteria, Bacteroidetes ve Fusobacteria şubelerinden patojenik olmayan ortak mikrobiyotadan oluşan benzersiz bir plasental mikrobiyom karakterize edilmiştir. İncelenen plasental mikrobiyom profillerinin en çok insan oral mikrobiyomuna benzediği tespit edilmiştir (Aagaard ve ark., 2014). Endometrial mikrobiyotanın incelemesi, mikrobiyota profilleri ile kadın sağllğı ve başarılı hamilelikler arasındaki yakın korelasyon nedeniyle büyük ilgi çekmektedir. Sezaryen doğumlarda endometrial mikrobiyotanın incelendiği pilot bir çalışmada insan mikrobiyotası içinde sınıflandırılabilen alt1 cins (Cutibacterium, Escherichia, Staphylococcus, Acinetobacter, Streptococcus, Corynebacterium) ortak bir bakteri bileşiminin varlığı gösterilmiştir (Leoni ve ark., 2019). 11-16 haftalık sağlıklı hamilelerin $(\mathrm{n}=182)$ vajinal mikrobiyomlarının karakterize edildiği ve hamile olmayan kadınların $(\mathrm{n}=310)$ vajinal mikrobiyomlarının karşılaştırıldığı bir araştırmada sağlıklı gebelerin vajinal mikrobiyomlarının düşük zenginlik ve çeşitliliğe, düşük Mycoplasma ve Ureaplasma prevalansına ve daha yüksek bakteri yüküne sahip olduğu tespit edilmiştir (Freitas ve ark., 2017).

Normal gebelerin vajinal mikrobiyotlarının kompozisyonu ve stabilitesinin hamile olmayan kadınlarınki ile karşılaştırıldığı bir çalışmada gebe kadınlarda Lactobacillus spp. varlığının anlamlı derecede yüksek olduğu bildirilmiştir. Ayrıca gebelik dönemindeki vajinal mikrobiyomun üreme çağındaki kadınlara nazaran daha yüksek stabilite gösterdiği belirtilmiştir (Romero ve ark., 2014). Benzer bir çalışmada da hamilelikte Lactobacillus türlerinin baskınlığı vurgulanmıştır (Freitas ve ark., 2017). Son yapılan çalışmada gebeliğe bağlı bu değişikliklerin açıklamalarının tam olarak belirlenemediği ancak steroid cinsiyet hormon düzeyleri ile vajinal mikrobiyomun kompozisyonu arasında bir ilişkiye dayandırıldığı ifade edilmiştir (Freitas ve ark., 2017). Bu bağlamda gebelikte östrojen seviyesindeki artı̧̧ı vajinal mukoza kalınlığının ve glikojen birikiminin artmasına neden olduğu bilinmektedir. Ayrıca, düşük vajinal pH'nın koruyucu etkisine katkıda bulunan laktik asitin üretimi için Lactobacillus spp. türlerinin ana karbonhidrat kaynağının glikojen olduğu da belirtilmektedir. Bu bilgiler doğrultusunda Lactobacillus türlerinin gebelikte daha fazla baskın olmasına ve bu kohorttaki zenginliğin ve çeşitliliğin azalmasına katkıda bulunabileceği ifade edilmiştir (Freitas ve ark., 2017).

\subsubsection{Yenidoğan Mikrobiyotası}

Yeni doğan mikrobiyotasının oluşumunda anneye ait mikrobiyotanın önem taşıdığı bilinmektedir. Yenidoğanların mikrobiyota kompozisyonunun büyük bir belirleyicisi ise doğum şeklidir. Normal doğan bebekler, maternal vajinal mikrobiyoma benzeyen bakteri toplulukları barındırırken, sezaryen doğan bebekler cilt mikrobiyotası ile zenginleştirilmiştir. Yenidoğanların vücudunu kolonize eden mikrobiyom, bağışıklık sisteminin eğitiminde belirleyici rol oynayabilir. Kommensal mikroorganizmalar ile erken etkileşim, uzun vadede sağlıklı bağışıklık gelişimiyle ilişkilendirilmektedir. Çocuklarda obezite riski ve bağışıklık bozuklukları üzerine yapılan çalışmalarda sezaryen doğum ile artmış obezite, astım, alerji ve immün yetmezlik riski arasında ilişki olduğu bildirilmiştir (Huh ve ark., 2012; Sevelsted ve ark., 2015; Dominguez-Bello ve ark., 2016).

Sezaryen doğumlu bebeklerin mikrobiyotasının vajinal mikrobiyal transfer ile kısmi restorasyonu üzerine yapılan pilot bir çalışmada sezaryen ile doğan bebeklerin mikrobiyota geri kazanımının uzun vadeli sağlık sonuçlarının belirsiz olduğu ancak doğum esnasında vajinal mikroorganizmaların kısmen geri alınabileceği belirtilmiştir (Dominguez-Bello ve ark., 2016). Yenidoğan bakteri çeşitliliğinin anal ve oral bölgelerde doğumda en yüksek seviyedeyken üçüncü günde azaldığı ve bunun yenidoğanın uterusta kazandığı kolonizasyon ile açıklabileceği ileri sürülmüştür. Buna karşın yenidoğan cildindeki

$41 \mid \mathrm{P}$ a g e 
bakteriyel çeşitliliğin doğumda en düşük seviyede olduğu ve yaşamın ilk ayında kademeli olarak arttığ1 bildirilmiştir. Bununla birlikte yenidoğan bebeklerin doğuştan hangi anahtar türleri taşıması gerektiğininin belirlenmesi sezaryen doğumlarda da vajinal doğumun sağladı̆̆ı faydalı etkilerin çoğaltılmasında önemli olacağı belirtilmiştir (Dominguez-Bello ve ark., 2016).

Son zamanlarda yapılan çalışmalarda doğum şekline ek olarak anne sütünün emzirilen çocuğun barsak mikrobiyotasının yerleşimine katkıda bulunduğu bildirilmiştir (Boix-Amorós ve ark., 2019). Anne sütündeki oligosakaritlerde ve süt mikrobiyotasındaki farklılıkların emzirilen bebeğin barsak mikrobiyotası üzerindeki etkisini değiştirerek bebek bağışılık sistemini şekillendirebileceği ve bu sayede akciğer sağlığ1 ve astım gelişimini etkileyebileceği ileri sürülmüştür (Moossavi ve ark., 2018).

Yenidoğan gastro intestinal yolunda kolonileşmenin incelendiği bir araştırmada mekonyumda ilk kez yaşamın üç domanininin (bakteri, arke, ökaryot) varlığı ispatlanmıştır. Bakterilere ek olarak arke ve mikro ökaryotların (baskın olarak fungusların) mekonyum örneklerinde tespit edildiği bildirilmiştir (Wampach ve ark., 2017). Son dönemde yeni doğan mekonyum mikrobiyotasının kaynağının belirlenmesi oldukça ilgi çeknektedir. Bu bağlamda birkaç teorinin var olmasına karşın kesin bilgi bulunmamaktadır (Wampach ve ark., 2017). Stinson ve ark. (2019) çok sayıda çalışmada insan mikrobiyomunun uteroda başlayabileceğinin öne sürüldüğünü ancak bu verilerin kontaminasyon sorunları nedeniyle tartışmaya açık olduğunu ifade etmişlerdir. Mikrobiyom iş akışlarında kontaminasyon ihtimali dikkate alınarak yürütülen bir çalışmada incelenen tüm mekonyum örnekleri ve çoğu amniyotik sıvı örneklerinde bakteri DNA'sı tespit edilmiştir. Bununla birlikte mekonyumda en baskın bakteri türünün Pelomonas puraquae olduğu, amniyotik sıv1 mikrobiyomunda ise Propionibacterium acnes ve Staphylococcus spp. türlerinin olduğu bildirilmiştir. Bu çalışma sonucunda

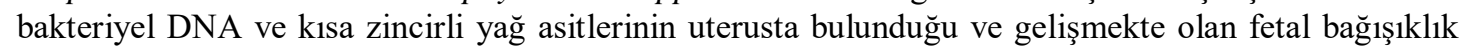
sistemini etkileme potansiyeline sahip olduğu ifade edilmiştir (Stinson ve ark., 2019).

\subsection{3 Ürogenital Mikrobiyom ve Sağllk}

Mikrobiyotanın sağlık ve hastalıklardaki gerçek rolünü daha iyi anlamak için büyük çabalar sarfedilmektedir (Peterson ve ark., 2009). Normal veya sağlıklı vajinanın ayırt edici özelliği olarak tanımlanan Lactobacillus türleri bulundukları ortamı yerleşik olmayan ve potansiyel olarak zararlı mikroorganizmalardan korumada laktik asit üretimine bağlı olarak önemli bir rol oynadığı bilinmektedir. Laktik asidin, insan immün yetmezlik virüsü (HIV) veya Neisseria gonorrhea gibi patojenlere karşı bir mikrobisit olarak etkili olduğu ifade edilmektedir (Sobel, 1999). Dahası laktik asit varlığında Gram negatif bakterilere maruz kalmanın konakçı doğal immün savunma sistemi üzerinde uyarıcı etkilere sahip olduğu belirtilmektedir (Ma ve ark., 2012). L. crispatus, Prevotella bivia ve Atopobium vaginae türleri gibi yaygın bakterilere sahip vajinal epitel hücre tabakalarının in vitro kolonizasyonunun kullanıldığı bir çalışmada, bu anahtar vajinal bakterilerin, epitel doğal bağışıklığı türe özgü bir şekilde düzenlediği gösterilmiştir (Fichorova ve ark. 2011).

İnsan ürogenital sistemi ve orada bulunan bakteri toplulukları, iyi dengelenmiş karşılıklı ilişki için bir örnektir. Bu ilişkide konakçı bakteri üremesini desteklemek için gereken besinlerin sağlanmasında mikrobiyal topluluklara katkıda bulunmaktadır. Gerekli besin maddelerinin bir kısmı hücre döküntülerinden, bazıları ise salgılardan elde edilmektedir. Diğer yandan, endojen bakteri toplulukları, semptomatik bakteriyel vajinoz, maya enfeksiyonları, cinsel yolla bulaşan enfeksiyonlar ve idrar yolu enfeksiyonlarından sorumlu olanlar da dahil olmak üzere potansiyel olarak patojenik organizmalar tarafından konağın kolonizasyonunun önlenmesinde koruyucu bir rol oynamaktadır (Ma ve ark., 2012). Lactobacillus türlerinin antimikrobiyal madde üretimi dikkate alındığında vajinal kaynaklı olanların laktik asit üretimine ek olarak hedefe özgü bakteriyosin ve geniş spektrumlu hidrojen peroksit ürettiğ $i$ bilinmektedir. Protein yapida olan bakteriyosinler, bakteri tarafindan sentezlenen dar spektrumlu antibakteriyal maddelerdir (Hawes ve ark., 1996; Karaoğlu ve ark., 2003). Bakteriyosinler vajinada endojen olmayan veya patojenik organizmaların büyümesini önlemede önemli bir rol oynayabilir. Hidrojen peroksit potansiyel patojen bakterilerin in vivo kolonizasyonunu inhibe edebilen başka bir antimikrobiyal bileşiktir (Dover ve ark., 2008). Ayrıca hidrojen peroksitin fizyolojik konsantrasyonlarının araştırıldığı bir çalışmada anaerobik büyüme koşulları altındaki 17 bakteriyel vajinozla ilişkili bakteri üzerinde saptanabilir bir etkisinin olmadığı ve vajinal sıvının hidrojen peroksitin antimikrobiyal aktivitesini engelleyebileceği gösterilmiştir. Dolayısıyla hidrojen peroksitin yerine laktik asidin vajinal mikrobiyotayı koruyucu rolüne katkıda bulunmasının daha muhtemel olduğu belirtilmiştir (O'Hanlon ve ark., 2011). 
Bakteriyel vajinozis (BV) tanılanması ve tedavisi oldukça zor olan ürogenital sistemde oldukça yaygın görülen, normal vajinal mikrobiyotanın dengesizliği olarak tanımlanan bir hastalıktır (Ma ve ark., 2012). BV vajinal mikrobiyotada Lactobacillus crispatus ve Lactobacillus jensenii gibi normal Lactobacillus dominant türlerin tükenmesi ve yerine Gardnerella vaginalis, Atopobium vaginae türleri ve Anaerococcus, Clostridium, Peptoniphilus ve Prevotella cinsleri gibi kommensal anaerobik bakterilerin büyümesi olarak ifade edilmektedir. (Fenollar ve Raoult, 2016). Bakteriyel vajinozun global epidemiyolojisinin sistematik bir derlemesin yapıldığ 1 çalışmada Türkiye'deki BV prevalansının $\% 23,2$ olduğu belirtilmiştir (Kenyon ve ark., 2013).

Menapoz ve vajinal mikrobiyota üzerine yapılan bir çalışmada menopoz sonrası kadınlarda vajinal mikrobiyomda Lactobacillus spp'yi eski haline getirmek için hem oral probiyotik formülasyonlarının alınması hem de probiyotiklerin vajinal aşılanmasının, sağlıklı vajinal mikrobiyomun geri kazanılması için umut verici olduğu belirtilmiştir (Mühleisen ve Herbst-Kralovetz, 2016).

İnsan mikrobiyotasının kültüre edildiği bir çalışmada Fekal mikrobiyota nakline (FMT) benzer şekilde vajinal mikrobiyota transplantasyonu faydalı vajinal mikrobiyal toplulukları restore ederek mukozal mikrobiyota dengesizliğini tedavi etmek için bir ç̧̈züm olabileceği ifade edilmiştir (Lagier ve ark., 2018). Benzer bir çalışmada kadınlarda görülen bir diğer önemli hastalık olan vulvavajinal atrofi (VVA)'de etkili bir tedavi yöntemi olarak hormon replasman tedavisi (HRT) uygulandığ 1 bildirilmiştir. $\mathrm{Bu}$ tedavide kullanılan östrojenin sadece vajinal semptomları iyileştirmekle kalmadığı, aynı zamanda menopoz sonrası vajinanın Lactobacillus türleriyle yeniden kolonizasyonuna olanak sağladığı ifade edilmiştir (Mühleisen ve Herbst-Kralovetz, 2016). Araştırmacılar tarafindan vajinal homeostaziyi restore etmek veya vajinal semptomları önlemek ve kadınların yaşam kalitesini iyileştirmek için yapılan çalışmalarda kişiselleştirilmiş bakteriyel terapötikler, prebiyotikler veya metabolitlerin kullanımının giderek artacağı ileri sürülmüştür (Mühleisen ve Herbst-Kralovetz, 2016).

\section{Sonuc}

Normalde insan vücuduyla ilişkilendirilen mikrobiyota insan gelişimi, fizyolojisi, bağışıklık ve beslenmede önemli bir etkiye sahiptir. Bu mikrobiyal toplulukların, hastalıklara neden olan yerleşik olmayıp istilacı organizmaları rekabetçi bir şekilde dışlayarak enfeksiyona karşı birinci savunma hattını oluşturduğuna inanılmaktadır (Peterson ve ark., 2009). Yapılan çoğu araştırma insan mikrobiyotası ve insan sağ lığı arasındaki ilişkiyi ortaya çıkarmaya yöneliktir. İnsan mikrobiyom projesinin devamı olarak görülen bütünleştirici insan mikrobiyom projesi kapsamında belirlenen üç kohorttan biri gebelik ve erken doğum olarak belirlenmiştir. Bunu dikkate alarak insan vücudu ve ev sahipliği yaptığı mikroorganizmalar üzerine yapılan araştırmaların analiz edildiği bu derlemede mikrobiyotanın kadın ve yeni doğan sağlığ 1 üzerine etkisi irdelenmiştir. Kadınların üretkenlik, gebelik, menapoz öncesi ve sonrası gibi farklı yaşam döngülerinde mikrobiyotada meydana gelen değşimlerin araştırılması ve sağlıklı bir çekirdek mikrobiyomun belirlenmesi mikrobiyal kökenli ürogenital hastalıkların teşhis ve tedavisinde büyük önem taşımaktadır. Sağlkklı bir vajen mikrobiyomunun gerek laktik asit gerekse bakteriyosin üreterek bulunduğu bölgeyi patojen mikroorganizmalardan koruduğu bilinse de etki mekanizmaları tam olarak belirlenmiş değildir. Bununla birlikte yeni antimikrobiyal etkileşimlerin keşfedilmesi mevcut tedavi yöntemlerinin iyileştirilmesine katkıda bulunabilir.

Yapılan çalışmalar sağlıklı bir anne mikrobiyotasının yenidoğan, bebeklik ve çocukluk gibi yaşamın ilk dönemlerinde sağlıklı bir mikrobiyotanın temelini oluşturduğunu göstermektedir. Yenidoğan bebeklerde cildin ilk kolonizasyonun normal doğumda anneye ait vajinal mikrobiyotaya, sezeryan doğumda ise anneye ait cilt mikrobiyotasına sahip olduğu dolayısıyla doğum şekliyle bağlantılı olduğu birçok araştırmacı tarafından ifade edilmiştir. Ancak yenidoğan cilt mikrobiyotasının oluşumunun sağlık üzerine uzun vadedeki etkileri tam olarak bilinmemektedir. Genel olarak fetal birçok bölgenin steril olduğu ifade edilse de plasenta ve mekonyumda mikroorganizmaların keşfedilmesi yenidoğan mikrobiyomu hakkında bilinen gerçekleri değiştirmekte ve kaynağı hakkında tartışmalara neden olmaktadır. Bu nedenlerle sağlıklı bir mikrobiyomun belirlenmesi ve kesin verilerin elde edilebilmesi için anne ve yenidoğan mikrobiyotası üzerine daha ileri araştırmalara ihtiyaç duyulmaktadır.

\section{Kaynaklar}

Aagaard, K., Ma, J., Antony, K. M., Ganu, R., Petrosino, J., \& Versalovic, J. (2014). The placenta harbors a unique microbiome. Science translational medicine, 6(237), 237ra65 
Aas, J. A., Paster, B. J., Stokes, L. N., Olsen, I., \& Dewhirst, F. E. (2005). Defining the normal bacterial flora of the oral cavity. Journal of clinical microbiology, 43(11), 5721-5732.

Antonio, M. A., Hawes, S. E., \& Hillier, S. L. (1999). The identification of vaginal Lactobacillus species and the demographic and microbiologic characteristics of women colonized by these species. Journal of Infectious Diseases, 180(6), 1950-1956.

Bäckhed, F., Roswall, J., Peng, Y., Feng, Q., Jia, H., Kovatcheva-Datchary, P., ... \& Khan, M. T. (2015). Dynamics and stabilization of the human gut microbiome during the first year of life. Cell host \& microbe, 17(5), 690-703.

Bassis, C. M., Tang, A. L., Young, V. B., \& Pynnonen, M. A. (2014). The nasal cavity microbiota of healthy adults. Microbiome, 2(1), 27.

Biasucci, G., Rubini, M., Riboni, S., Morelli, L., Bessi, E., \& Retetangos, C. (2010). Mode of delivery affects the bacterial community in the newborn gut. Early human development, 86(1), 13-15.

Biswas, K., Hoggard, M., Jain, R., Taylor, M. W., \& Douglas, R. G. (2015). The nasal microbiota in health and disease: variation within and between subjects. Frontiers in microbiology, 6, 134.

Boix-Amorós, A., Puente-Sánchez, F., du Toit, E., Linderborg, K. M., Zhang, Y., Yang, B., ... \& Collado, M. C. (2019). Mycobiome Profiles in Breast Milk from Healthy Women Depend on Mode of Delivery, Geographic Location, and Interaction with Bacteria. Appl. Environ. Microbiol., 85(9), e02994-18.

Byrd, A. L., Belkaid, Y. and Segre J. A. (2018). The human skin microbiome Nature Reviews Microbiology volume 16, pages 143-155.

Chen, K. and Pachter, L. (2005). Bioinformatics for Whole-Genome Shotgun Sequencing of Microbial Communities. PLOS Computational Biology 1(2): e24. https://doi.org/10.1371/journal.pcbi.0010024

Dethlefsen, L., McFall-Ngai, M. ve Relman, D. (2007). An ecological and evolutionary perspective on human-microbe mutualism and disease. Nature 449, 811-818. doi:10.1038/nature06245

Di Bella, J. M., Bao, Y., Gloor, G. B., Burton, J. P., \& Reid, G. (2013). High throughput sequencing methods and analysis for microbiome research. Journal of microbiological methods, 95(3), 401414.

Dominguez-Bello, M. G., Costello, E. K., Contreras, M., Magris, M., Hidalgo, G., Fierer, N., \& Knight, R. (2010). Delivery mode shapes the acquisition and structure of the initial microbiota across multiple body habitats in newborns. Proceedings of the National Academy of Sciences, 107(26), 11971-11975.

Dominguez-Bello, M. G., De Jesus-Laboy, K. M., Shen, N., Cox, L. M., Amir, A., Gonzalez, A., Bokulich, N. A., Song, S. J., Hoashi, M., Rivera-Vinas, J. I., Mendez, K., Knight, R. \& Clemente, J. C. (2016). Partial restoration of the microbiota of cesarean-born infants via vaginal microbial transfer. Nature medicine, 22(3), 250.

Donia, M. S., Cimermancic, P., Schulze, C. J., Wieland Brown, L. C., Martin, J., Mitreva, M., ... Fischbach, M. A. (2014). A systematic analysis of biosynthetic gene clusters in the human microbiome reveals a common family of antibiotics. Cell, 158(6), 1402-1414. doi: 10.1016/j.cell.2014.08.032

Dover, S. E., Aroutcheva, A. A., Faro, S., \& Chikindas, M. L. (2008). Natural antimicrobials and their role in vaginal health: a short review. International journal of probiotics \& prebiotics, 3(4), 219. 
Falsen, E., Pascual, C., Sjödén, B., Ohlén, M., \& Collins, M. D. (1999). Phenotypic and phylogenetic characterization of a novel Lactobacillus species from human sources: description of Lactobacillus iners sp. nov. International Journal of Systematic and Evolutionary Microbiology, 49(1), 217-221.

Fenollar, F. \& Raoult, D. (2016). Does bacterial vaginosis result from fecal transplantation? J. Infect. Dis. $214,1784$.

Fichorova, R. N., Yamamoto, H. S., Delaney, M. L., Onderdonk, A. B., \& Doncel, G. F. (2011). Novel vaginal microflora colonization model providing new insight into microbicide mechanism of action. MBio, 2(6), e00168-11.

Fierer, N., Lauber, C. L., Zhou, N., McDonald, D., Costello, E. K., \& Knight, R. (2010). Forensic identification using skin bacterial communities. Proceedings of the National Academy of Sciences, 107(14), 6477-6481.

Freitas, A. C., Chaban, B., Bocking, A., Rocco, M., Yang, S., Hill, J. E., \& Money, D. M. (2017). The vaginal microbiome of pregnant women is less rich and diverse, with lower prevalence of Mollicutes, compared to non-pregnant women. Scientific reports, 7(1), 9212.

Gilbert, J. (2015). The Microbiome Project: Dogs. ANL (Argonne National Laboratory (ANL), Argonne, IL, United States). [Online] Available: https://www.anl.gov/article/home-is-where-themicrobes-are-home-microbiome-project-announces-results-of-study-on-household (August 7, 2019)

Gilbert, J. A., Jansson, J. K., \& Knight, R. (2014). The Earth Microbiome project: successes and aspirations. BMC biology, 12(1), 69.

Grice, E. A., \& Segre, J. A. (2011). The skin microbiome. Nature reviews. Microbiology, 9(4), 244 253. doi:10.1038/nrmicro2537.

Grice, E. A., Kong, H. H., Conlan, S., Deming, C. B., Davis, J., Young, A. C., ... Segre, J. A. (2009). Topographical and temporal diversity of the human skin microbiome. Science (New York, N.Y.), 324(5931), 1190-1192. doi:10.1126/science.1171700.

Gritz, E. C., \& Bhandari, V. (2015). The human neonatal gut microbiome: a brief review. Frontiers in pediatrics, 3,17 .

Hampton-Marcell, J. T., Lopez, J. V., \& Gilbert, J. A. (2017). The human microbiome: an emerging tool in forensics. Microbial biotechnology, 10(2), 228-230. doi:10.1111/1751-7915.12699.

Hawes, S. E., Hillier, S. L., Benedetti, J., Stevens, C. E., Koutsky, L. A., Wølner-Hanssen, P., \& Holmes, K. K. (1996). Hydrogen peroxide-producing lactobacilli and acquisition of vaginal infections. Journal of Infectious Diseases, 174(5), 1058-1063.

Hickey, R.J., Zhou, X., Pierson, J.D., Ravel, J., Forney, L.J. (2012). Understanding vaginal microbiome complexity from an ecological perspective. Transl. Res.160:267-282.

Huh, S. Y., Rifas-Shiman, S. L., Zera, C. A., Edwards, J. W. R., Oken, E., Weiss, S. T., \& Gillman, M. W. (2012). Delivery by caesarean section and risk of obesity in preschool age children: a prospective cohort study. Archives of disease in childhood, 97(7), 610-616.

Huttenhower, C., Gevers, D., Knight, R. et al. (2012). Structure, function and diversity of the healthy human microbiome. Nature 486, 207-214. doi:10.1038/nature11234.

International Human Genome Sequencing Consortium (IHGSC). (2004). Finishing the euchromatic sequence of the human genome. Nature, 431, 931-945. doi:10.1038/nature03001 
Integrative Human Microbiome Project (iHMP) Research Network Consortium. (2014). The Integrative Human Microbiome Project: dynamic analysis of microbiome-host omics profiles during periods of human health and disease. Cell host \& microbe, 16(3), 276-289. doi: 10.1016/j.chom.2014.08.014.

Jiménez, E., Marín, M. L., Martín, R., Odriozola, J. M., Olivares, M., Xaus, J., ... \& Rodríguez, J. M. (2008). Is meconium from healthy newborns actually sterile? Research in microbiology, 159(3), $187-193$

Jost, T., Lacroix, C., Braegger, C. P., Rochat, F., \& Chassard, C. (2014). Vertical mother-neonate transfer of maternal gut bacteria via breastfeeding. Environmental microbiology, 16(9), 28912904.

Karaoğlu, Ş. A., Aydin, F., Kilic, S. S., \& Kilic, A. O. (2003). Antimicrobial activity and characteristics of bacteriocins produced by vaginal lactobacilli. Turkish Journal of Medical Sciences, 33(1), 7-13.

Kenyon, C., Colebunders, R., \& Crucitti, T. (2013). The global epidemiology of bacterial vaginosis: a systematic review. American journal of obstetrics and gynecology, 209(6), 505-523.

Krishna, S. B. N., Wilson, S. L., \& Adam, J. K. (2017). The vaginal microbiota in women health and disease: current understanding and future perspectives-a review.

Kuehnert, M. J., Kruszon-Moran, D., Hill, H. A., McQuillan, G., McAllister, S. K., Fosheim, G., ... \& Killgore, G. (2006). Prevalence of Staphylococcus aureus nasal colonization in the United States, 2001-2002. Journal of Infectious Diseases, 193(2), 172-179.

Lagier, J. C., Dubourg, G., Million, M., Cadoret, F., Bilen, M., Fenollar, F., ... \& Raoult, D. (2018). Culturing the human microbiota and culturomics. Nature Reviews Microbiology, 16(9), 540.

Lax, S., Hampton-Marcell, J. T., Gibbons, S. M., Colares, G. B., Smith, D., Eisen, J. A., \& Gilbert, J. A. (2015). Forensic analysis of the microbiome of phones and shoes. Microbiome, 3(1), 21.

Lax, S., Smith, D. P., Hampton-Marcell, J., Owens, S. M., Handley, K. M., Scott, N. M., ... \& Metcalf, J. L. (2014). Longitudinal analysis of microbial interaction between humans and the indoor environment. Science, 345(6200), 1048-1052.

Leoni, C., Ceci, O., Manzari, C., Fosso, B., Volpicella, M., Ferrari, A., ... \& Ceci, L. R. 2019. Human Endometrial Microbiota at Term of Normal Pregnancies. Genes, 10(12), 971.

Lloyd-Price, J., Abu-Ali, G., \& Huttenhower, C. (2016). The healthy human microbiome. Genome medicine, 8(1), 51.

Ma, B., Forney, L. J., \& Ravel, J. (2012). Vaginal microbiome: rethinking health and disease. Annual review of microbiology, 66, 371-389. doi:10.1146/annurev-micro-092611-150157.

Mahdavinia, M., Keshavarzian, A., Tobin, M. C., Landay, A. L., \& Schleimer, R. P. (2016). A comprehensive review of the nasal microbiome in chronic rhinosinusitis (CRS). Clinical \& Experimental Allergy, 46(1), 21-41.

Man, W. H., de Steenhuijsen Piters, W. A., \& Bogaert, D. (2017). The microbiota of the respiratory tract: gatekeeper to respiratory health. Nature Reviews Microbiology, 15(5), 259.

Marcobal, A., Barboza, M., Sonnenburg, E. D., Pudlo, N., Martens, E. C., Desai, P., ... \& Sonnenburg, J. L. (2011). Bacteroides in the infant gut consume milk oligosaccharides via mucus-utilization pathways. Cell host \& microbe, 10(5), 507-514. 
Martin, D.H. (2012). The microbiota of the vagina and its influence on women's health and disease. Am. J. Med. Sci. 343(1):2-9.

Meadow, J. F., Altrichter, A. E., \& Green, J. L. (2014). Mobile phones carry the personal microbiome of their owners. PeerJ, 2, e447.

Methé, B., Nelson, K., Pop, M. et al. (2012). A framework for human microbiome research. Nature 486, 215-221. doi:10.1038/nature11209.

Mirmonsef, P., Hotton, A.L., Gilbert, D., Burgad, D., Landay, A., Weber, K.M., Cohen, M., Ravel, J., Spear, G.T. (2014). Free glycogen in vaginal fluids is associated with Lactobacillus colonization and low vaginal pH. PLoS One. 9:e102467.

Moossavi, S., Miliku, K., Sepehri, S., Khafipour, E., \& Azad, M. B. (2018). The Prebiotic and Probiotic Properties of Human Milk: Implications for Infant Immune Development and Pediatric Asthma. Frontiers in pediatrics, 6, 197. doi:10.3389/fped.2018.00197.

Muhleisen, A. L., \& Herbst-Kralovetz, M. M. (2016). Menopause and the vaginal microbiome. Maturitas, 91, 42-50.

O'Hanlon, D. E., Moench, T. R., \& Cone, R. A. (2011). In vaginal fluid, bacteria associated with bacterial vaginosis can be suppressed with lactic acid but not hydrogen peroxide. BMC infectious diseases, 11(1), 200.

Peterson J, Garges S, Giovanni M, McInnes P, Wang L, Schloss JA, Bonazzi V, McEwen JE, Wetterstrand KA, Deal C, Baker CC, Di Francesco V, Howcroft TK, Karp RW, Lunsford RD, Wellington CR, Belachew T, Wright M, Giblin C, David H, Mills M, Salomon R, Mullins C, Akolkar B, Begg L, Davis C, Grandison L, Humble M, Khalsa J, et al. (2009). The NIH Human Microbiome Project. Genome Res. 19(12):2317-2323. doi: 10.1101/gr.096651.109.

Qin, J., Li, R., Raes, J., Arumugam, M., Burgdorf, K. S., Manichanh, C., .. \& Mende, D. R. (2010). A human gut microbial gene catalogue established by metagenomic sequencing. Nature, 464(7285), 59.

Rajilić-Stojanović, M., \& de Vos, W. M. (2014). The first 1000 cultured species of the human gastrointestinal microbiota. FEMS microbiology reviews, 38(5), 996-1047. doi:10.1111/15746976.12075

Ramakrishnan, V. R., Holt, J., Nelson, L. F., Robertson, C. E., \& Frank, D. N. (2018). Determinants of the Nasal Microbiome: Pilot Study of Effects of Intranasal Medication Use. Allergy \& Rhinology, 9, 2152656718789519.

Rautava, S., Collado, M. C., Salminen, S., \& Isolauri, E. (2012). Probiotics modulate host-microbe interaction in the placenta and fetal gut: a randomized, double-blind, placebo-controlled trial. Neonatology, 102(3), 178-184.

Ravel, J., Gajer, P., Abdo, Z., Schneider, G. M., Koenig, S. S., McCulle, S. L., ... \& Brotman, R. M. (2011). Vaginal microbiome of reproductive-age women. Proceedings of the National Academy of Sciences, 108(Supplement 1), 4680-4687.

Rawls, M., \& Ellis, A. K. (2019). The microbiome of the nose. Annals of Allergy, Asthma \& Immunology, 122(1), 17-24.

Richter, T. K., S., Michalski, J. M., Zanetti, L., Tennant, S. M., Chen, W. H., \& Rasko, D. A. (2018). Responses of the human gut escherichia coli population to pathogen and antibiotic disturbances. MSystems, 3(4):1-15. doi: http://dx.doi.org/10.1128/mSystems.00047-18. 
Roberts, L. (2001). Timeline: A History of the Human Genome Project. Science, 291(5507), 11951200 .

Romero, R., Hassan, S. S., Gajer, P., Tarca, A. L., Fadrosh, D. W., Nikita, L., ... Ravel, J. (2014). The composition and stability of the vaginal microbiota of normal pregnant women is different from that of non-pregnant women. Microbiome, 2(1), 4. doi:10.1186/2049-2618-2-4.

Segata, N., Haake, S. K., Mannon, P., Lemon, K. P., Waldron, L., Gevers, D., Huttenhower, C., Izard, J. (2012). Composition of the adult digestive tract bacterial microbiome based on seven mouth surfaces, tonsils, throat and stool samples. Genome biology, 13(6), R42.

Sender, R., Fuchs, S., \& Milo, R. (2016). Revised estimates for the number of human and bacteria cells in the body. PLoS biology, 14(8), e1002533.

Sevelsted, A., Stokholm, J., Bønnelykke, K., \& Bisgaard, H. (2015). Cesarean section and chronic immune disorders. Pediatrics, 135(1), e92-e98.

Smith, D., Alverdy, J., An, G., Coleman, M., Garcia-Houchins, S., Green, J., ... \& Levin, H. (2013). The Hospital Microbiome Project: Meeting Report for the 1st Hospital Microbiome Project Workshop on sampling design and building science measurements, Chicago, USA, June 7th-8th 2012. Standards in genomic sciences, 8(1), 112.

Sobel, J. D. (1999). Is there a protective role for vaginal flora? Current infectious disease reports, $1(4), 379$

Stinson, L.F., Boyce, M.C., Payne, M.S. and Keelan, J.A. (2019). The not-so-sterile womb: Evidence that the human fetus is exposed to bacteria prior to birth. Frontiers in microbiology, 10, p.1124.

Turnbaugh, P. J., Ley, R. E., Hamady, M., Fraser-Liggett, C. M., Knight, R., \& Gordon, J. I. (2007). The human microbiome project. Nature, 449(7164), 804.

Venter J. C., Adams, M. D., Myers, E. W., Li, P. W., Mural, R. J., Sutton, G. G., ... \& Gocayne, J. D. (2001). The sequence of the human genome. Science, 291(5507), 1304-1351.

Wampach, L., Heintz-Buschart, A., Hogan, A., Muller, E.E., Narayanasamy, S., Laczny, C.C., Hugerth, L.W., Bindl, L., Bottu, J., Andersson, A.F. and de Beaufort, C. (2017). Colonization and succession within the human gut microbiome by archaea, bacteria, and microeukaryotes during the first year of life. Frontiers in microbiology, 8, p.738.

Wassenaar, T. M., \& Panigrahi, P. (2014). Is a foetus developing in a sterile environment? Letters in applied microbiology, 59(6), 572-579.

Yatsunenko, T., Rey, F. E., Manary, M. J., Trehan, I., Dominguez-Bello, M. G., Contreras, M., ... Gordon, J. I. (2012). Human gut microbiome viewed across age and geography. Nature, 486(7402), 222-227. doi:10.1038/nature11053

Zhou, X., Bent, S. J., Schneider, M. G., Davis, C. C., Islam, M. R., \& Forney, L. J. (2004). Characterization of vaginal microbial communities in adult healthy women using cultivationindependent methods. Microbiology, 150(8), 2565-2573.

Zhou, Y., Mihindukulasuriya, K.A., Gao, H., La Rosa, P.S., Wylie, K.M., Martin, J.C., Kota, K., Shannon, W.D., Mitreva, M., Sodergren, E. and Weinstock, G.M. (2014). Exploration of bacterial community classes in major human habitats. Genome biology, 15(5), p.R66. 